\title{
A Stylistic Analysis of Chinua Achebe's Things Fall Apart
}

\section{Marcella Melly Kosasih}

\author{
Maranatha Christian University, Indonesia \\ Email: melly_kosasih@yahoo.com
}

\begin{abstract}
The present research aims to analyze the writing style of Chinua Achebe in his novel Things Fall Apart. The focus of this research is a stylistic analysis of figures of speech, as classified by Leech and Short as one of stylistic categories, in connection with the author's purpose of delivering his message to the readers. The findings of the research confirmed that some figures of speech, such as metaphor, simile, personification, and onomatopoeia, are foregrounded by the author to convey meaning and heighten effect so that they helped transmit the author's purpose. They were used to describe the characterization of the protagonist, the description of the white men as the antagonist, the description of the Igbo's traditions, and the description of the setting of place. Chinua Achebe has successfully made use of the figures of speech to clearly describe the unique life of the native Africans.
\end{abstract}

Keywords-author's purpose, figures of speech, stylistics.

\section{INTRODUCTION}

Albert Chinualumogu Achebe (November 16, 1930 March 21, 2013) was a Nigerian writer. He was called "the father of modern African writing" and played a pivotal role in the African literature. He wrote more than 20 books of different genres: novels, short stories, essays, and collections of poetry. For his literary career, he was presented the Man Booker International Prize in 2007. ("Chinua Achebe Biography") $\mathrm{He}$ is also acclaimed as "the writer who invented African literature" (Gikandi, 1996, p. ix).

Things Falls Apart (1958) was his debut novel and one of the first African novels originally written in English that acquired worldwide acclaim. It has sold 12 million copies worldwide and has been translated into more than 50 languages. It tells about a culture on the verge of change; about the traditional Igbo life at the time of the advent of missionaries and colonial government at the turn of the twentieth century. The protagonist of the novel, Okonkwo, cannot accept the new order and commits suicide. The novel itself was written in response to
European novels that depicted Africans as uncivilized and uneducated who needed to be enlightened by the Europeans (Achebe, 1978 , p.9). Through Things Fall Apart, Achebe wanted to give insights to the world that Africans have their own traditional and cultural identity in order that Europeans become more appreciative of Africa. Being a native African and a conscious artist, he also "penetrates through the root cause of the problems of his native fellow beings" (Maleki and Navidi, 2011, p. 12). In order to better understand what the author wants to convey, his style of writing is worth analyzing.

Style, according to Wales (2011), is the set of features peculiar to, or characteristics of an author: his or her language habits or idiolect. David Lodge in The Language of Fiction (1966) has made his significant statement: "The novelist's medium is language: what he does, qua novelist, he does in and through language" (p. ix). It reveals how a writer effectively delivers his ideas through language. Leech and Short (2007) elaborate that style is "the linguistic characteristics of a particular text" (p. 11). 
There have been many researches and reviews by critics and readers of Things Fall Apart. However, most of the researches focused on post colonialism and few of them were done on the linguistic features and literary devices, that is, the stylistic features. Jweid (2016), for example, focused on deteriorating national identity of the Nigerian society. The life of the protagonist was examined through postcolonial concepts, namely aboriginality, hegemony, subaltern and identity (p. 531). The death of the protagonist due to his committing suicide reflected the fall of the Nigerian indigenous identity.

Salami and Tabari (2018) also discussed the novel from post-colonial discourse by using some theories from Homi Bhabha and Michael Bakhtin. The research comes to the conclusion that "Things Fall Apart can be taken as a postcolonial discourse drawing on the pre-colonial as well as the colonial Nigerian on an objective manner in order to help the Nigerian readers find how to piece together what once fall apart" (p.27).

The present research tries to analyze Things Fall Apart by means of literary stylistics. Stylistics, according to Verdonk (2002), is defined as "the analysis of distinctive expression in language and the description of its purpose and effect" (p.4). Widdowson (1975) defines stylistics as "the study of literary discourse from a linguistic orientation" (p.4). It is the link between literary criticism and linguistics. According to Leech and Short (2007), stylistics is simply defined as the (linguistic) study of style and it has the goal of explaining "how language serves a particular artistic function" (p.11).

This research will deal with the stylistic analysis of Chinua Achebe's novel entitled Things Fall Apart. The researcher would like to find out how the linguistic features, in this case the figures of speech, used by the writer in the novel perform their artistic function to help delivering the writer's message. In order to understand and appreciate the artistic function better, this research will answer the following questions:

1. Which figures of speech are used by Chinua Achebe in his novel Things Fall Apart?

2. How do these figures of speech help transmitting the writer's message?

\section{LITERATURE REVIEW}

Cacciari and Glucksberg (2007) stated that "figurative language is no longer perceived as merely an ornament added to everyday, straightforward literal language, but instead viewed as a powerful communicative and conceptual tool" (p. 448). They can serve as a medium to bridge communication and to deliver concepts. Leech and Short (2007) considered figures of speech "the incidence of features which are foregrounded by virtue of departing in some way from general norms of communication by means of language code" (p. 63). They stated that traditional figures of speech (schemes and tropes) are often useful for identifying such features as "exploitation of regularities of formal patterning, or of deviations from the linguistic code" (p.63). Figure of speech is simply defined as "a form of expression used to convey meaning by comparing or identifying one thing with another that has a meaning or connotation familiar to the reader" ("Figure of Speech"). The following definitions and examples are taken from an article written by Wheeler (2018). Figures of speech are divided into two types:

1. Tropes: Figures of speech with an unexpected twist in the meaning of words. Some figures of speech which are included in tropes are:

(a) Metaphor: When something is something else.

- The office is a bee-hive of activity on Mondays.

- This is your brain on drugs.

(b) Simile: When something is like something else.

- Her skin was like alabaster.

- He was as unpleasant as a wart.

(c) Synecdoche: Using a part of a physical object to represent the whole object.

- Twenty eyes watched our every move.

- All hands on deck!

(d) Personification: Giving human qualities to inanimate objects

-The ground thirsts for rain; the wind whispered secrets to us.

(e) Onomatopoeia: Words that sound like what they mean.

- buzz, rattle, click, clatter, crackle, and pop. 
(f) Hyperbole: Exaggeration.

- His thundering shout could split the rocks.

2. Schemes: Figures of speech that deal with word order, syntax, letters, and sounds. Some figures of speech which are included in schemes are:

(a) Parallelism: When the writer establishes similar patterns of grammatical structure and length.

- King Alfred tried to make the law clear, precise, and equitable.

- Her purpose was to impress the ignorant, to perplex the dubious, and to startle the complacent.

(b) Anaphora: repetition of beginning clause

- "We shall not flag or fail. We shall not go on to the end. We shall fight in France, we shall fight on the seas and oceans ...," declared Churchill.

(c) Diacope: uninterrupted repetition or repetition with only one or two words between each repeated phrase.

- "Oh, horror, horror, horror!"

\section{METHODOLOGY}

This research is qualitative descriptive. According to Sandelowski (2000), "Qualitative descriptive study is the method of choice when straight descriptions of phenomena are desired." The phenomena were described by interpreting the data collected, which were in the form of words rather than numbers (Bogdan and Biklen, 1997, p.10). Concerning the instrument of the study, purposeful sampling technique was used to obtain cases deemed rich in information for the purposes of completing the data (Sandelowski, 2000). The researcher has chosen Chinua Achebe's novel Things Fall Apart, which deals with native Nigerian protagonist's experience of coping with new culture and order brought by European missionaries. Data collection was focused on discovering the nature of the specific events related to the research problems. Thus, while reading the novel she focused on the foregrounded figures of speech used in the novel. The theories of figurative language were used to make sure that the data were valid and relevant. The writing style of Chinua Achebe in his Things Fall Apart was then identified based on the results of the analysis.

\section{DISCUSSION}

The stylistic analysis will focus on the figures of speech used in the novel in connection with their roles to serve the author's purpose. The story itself is narrated in a third person omniscient point of view. The narrator is the focal character who provides the reader with much information about what happens in the story. In narrating the story, several figures of speech are used, such as simile, metaphor, personification, onomatopoeia, and parallelism. They are used to describe almost all the characters and events but the researcher will only choose those which play a great role in the characterization of the protagonist, the description of the white men, the description of the setting of place, and the description of the Igbo traditions. These things are in accordance with the purpose of the author, Chinua Achebe, in writing the novel.

\subsection{Characterization of Okonkwo}

Okonkwo is the protagonist of the novel. In the beginning, he is portrayed as a great warrior of the Umuofia clan, a lower Nigerian tribe, but in the end he is nothing. In describing the development of his characteristics, the author, through the narration of the narrator, uses simile, metaphor, and hyperbole.

At the age of 18 , Okonkwo has brought honor to his village by defeating Amalinze Cat, the great wrestler who for seven years is undefeated, from Umuofia to Mbaino.

(1) Okonkwo was as slippery as a fish in water. (Achebe, 1995, p.1)

(2) ... he was a fierce fighter. (p.10)

The words used as a comparison to Okonkwo's character are effective. In wrestling, to win the game, one has to be difficult to hold and he fights fiercely; and Okonkwo has these characteristics to be the winner. Since then, Okonkwo is famous all over the area for years,

(3) Okonkwo was the great wrestler and warrior alive. (p.50)

(4) ... whose fame had grown like a bush-fire in the harmattan. (p.1)

(5) They treated Okonkwo like a king. (p.11)

From the simile and metaphor used, it is clear that Okonkwo is described positively. The nouns used as comparison, a fighter, a wrestler, a warrior, and even a 
king, give an impression that Okonkwo is manly, famous, and respected.

Another proof that Okonkwo considers strength important in a man can be seen when he talks about Nwoye, his eldest son.

(6) I am worried about Nwoye. A bowl of pounded-yams can throw him in a wrestling match. His two younger brothers are more promising. (p.27)

Here hyperbole is used to describe that Nwoye is so weak that a bowl of pounded yams can throw him in a wrestling match, not necessarily his opponent. Exaggeration is used to give dramatic effect. Okonkwo's comment on Nwoye's being a weak child implies that he actually wants a brave boy to be his son.

Simile is also used when Okonkwo feels guilty about killing Ikemefuna, which he actually ought to do to avoid being thought weak. He does not eat anything for two days and just drinks palm-wine.

(7) He drank palm-wine from morning till night, and his eyes were red and fierce like the eyes of a rat when it was caught by the tail and dashed against the floor. (p.25)

(8) Once he got up from bed and walked about his compound. But he was so weak that his legs could hardly carry him. He felt like a drunken giant walking with the limbs of a mosquito. (pp.25-26)

The author describes the condition of Okonkwo by using familiar animals such as a rat and a mosquito as the objects of comparison. Being given the explanation of the rat's eyes, the readers can easily grasp the idea of how red and fierce Okonkwo's eyes are (data 7). And in data (8), the readers can directly understand how Okonkwo feels at that time. Although he is compared to a drunken giant, that is believed to be strong, his limbs are compared to the limbs of a mosquito that cannot support the body of a giant. So, the figure of speech helps the readers in knowing clearly the condition Okonkwo is in. His guilty feeling has caused him to be drunk and too weak to walk.

Simile is also used when Okonkwo comes back to Umuofia after being exiled to his mother's village, Mbanta for seven years in order to make amends due to his killing a clansman. Killing a clansman is a serious crime against the earth goddess. He has to start from the beginning, and work very hard to plant a new farm.

(9) It was like beginning life anew without the vigor and enthusiasm of youth, like learning to become left-handed in old age. (p.53)

The words used in the simile give a clearer picture of what is explained, that life is very hard for Okonkwo. Beginning a new life and learning to become left-handed in old age are not easy things to do. Besides,

(10) Okonkwo's return to his native land was not as memorable as he had wished. (p.73)

Umuofia does not appear to have taken any special notice of the warrior's return as the thoughts of the people is occupied by the missionaries - their church, government, and trading stores. On returning to Umuofia, Okonkwo finds out that the white missionaries have gained a lot of ground.

(11) He mourned for the clan, which he saw breaking up and falling apart and he mourned for the warlike men of Umuofia, who had so unaccountably become soft like women. (p.74)

From the simile, the reader can conclude that Okonkwo is upset with their fellow clansmen who become weak in dealing with the coming of the new religion to their village and breaking them up.

Another simile and metaphor are used when Okonkwo is enraged and greatly troubled by his son Nwoye's betrayal of becoming a Christian.

(12) To abandon the gods of one's father and go about with a lot of effeminate men clucking like old hens was the very depth of abomination. Suppose when he died all his male children decided to follow Nwoye's steps and abandon their ancestors? Okonkwo felt a cold shudder run through him at the terrible prospect, like the prospect of annihilation. (63)

The simile shows that Okonkwo considers Nwoye's new religion weak and effeminate, characteristics that are 
opposite to his. For Okonkwo, manliness is very important. Through the metaphor, it is shown that Nwoye's abandoning the gods of his father and joining the weak Christians are disgusting. Moreover, the personification that follows strengthens how he feels about the prospect of his clan being destroyed completely once his children become Christians after his death. His attitudes clearly show that Okonkwo resists the new religious order.

The narrator uses another simile which clearly described how Okonkwo, who is at the beginning respected by the people, is in the end despised by them. This happens when he commits suicide. After he kills with his machete one of the court messengers sent by the District Commissioner, he finds it no use to live as he knows that people in Umuofia are cowards; they are not willing to go to war against the white men, who bring the new religion to and destroy the native culture of Umuofia.

(13) "That man was one of the greatest men in Umuofia. You drove him to kill himself and now he will be buried like a dog ...." (p.84)

The above statement is stated by Obierika, Okonkwo's best friend, Okonkwo's death is tragic because white men have caused a good man to kill himself (Achebe, 1996, p.84). The reader will give empathy to this particular character: The greatest and respected man in Umuofia has to end his life by committing suicide, which is an unforgivable sin, and thus, does not deserve a proper burial. The simile is effectively used to give a clear picture of the condition: The respected man is eventually compared to an animal. The death of Okonkwo reflects the defeat of the Igbo tradition against the new culture brought by the white.

\subsection{Description of the White Men}

The antagonist in this novel is the missionaries, the white men who bring the new religion, new government, and trading stores. They bring changes to the culture of the Igbo people. In describing the missionaries, the author also uses figures of speech, such as simile, metaphor, anaphora, and hyperbole.

(14) And so they killed the white man and tied his iron horse to their sacred tree because it looked as if it would run away to call the man's friends . ... It said that other white men were on their way. They were locusts, it said, and that first man was their harbinger sent to explore the terrain. (p. 57)

(15) At first, a fairly small swarm came. They were the harbingers sent to survey the land. And then appeared on the horizon a slowly-moving mass like a boundless sheet of black cloud drifting towards Umuofia. (p.23)

In data (14) the white men are compared to the locusts, which come to Umuofia after being absent for many years. Their coming has the same characteristic as the locusts'. At first the locusts come in a small group, and they are sent to survey the land (data 15) before a much larger group come; so the same as the first swarm of locusts, the first missionary who came to Umuofia is the harbinger, "a sign that something bad is going to happen soon" ("Harbinger"). He will be followed by other missionaries who will spread the new order in Umuofia and convert the clansmen to Christianity. That is why the native people kill the first white man to prevent the other white men's coming.

In connection with the coming of the white men, the events about the coming of the locusts are presented allegorically.

(16) And at last the locusts did descend. They settled on every tree and on every blade of grass, they settled on the roofs and covered the bare ground. Mighty tree branches broke away under them, and the whole country became the brown-earth colour of the vast, hungry swarm. (Achebe, 1996, p.23)

In data (16) anaphora is used. The repetition of the words 'they settled on...' and 'every' is to give emphasis to the fact that the locusts' presence is inescapable. The word 'settle' usually refers to the people who want to take control of other people's area. This foreshadows the inevitable arrival of the missionaries, which will settle in Umuofia and bring changes socially and politically to the Igbo people.

Another figure of speech is used to show how the people of Igbo see the first converts and the white men.

(17) Chielo, the priestess of Agbala, called the 
converts the excrement of the clan, and the new faith was a mad dog that had come to eat it up. (p.59)

The words used to make a comparison in the metaphor show that the priestess has a negative impression about the new faith and the people who are converted to it. The new faith and the converts are of no value in the eyes of the clansmen, which shows how the clansmen see the new faith brought by the missionaries.

One of the negative impacts of the new religion is the destruction of the bond of kinship among the Igbo people:

(18) An abominable religion has settled among you [young men]. A man can now leave his father and his brothers. He can curse the gods of his fathers and his ancestors, like a hunter's dog that suddenly goes mad and turns on his master. (p.68)

The simile is used to clearly describe the situation. The converted young man who curses the god of his fathers and ancestors is compared to a hunter's dog that suddenly goes mad and unexpectedly attacks his master; traditions are shattered by the new religion.

Reverend James Smith comes to Umuofia to replace Mr. Brown, the missionaries' leader. Mr. Brown never incites the vexation of the clan in preaching. His successor, however, is a different kind of man.

(19) He condemned openly Mr. Brown's policy of compromise and accommodation. He saw things as black and white. And black was evil. He saw the world as a battlefield to which the children of light were locked in mortal conflict with the sons of darkness. (p.74)

The metaphors clearly show Smith's perspective about black people and how he will deal with them. He considers black people to be evil and Umuofia a battlefield. In this case Achebe wants to criticize white writers who portray the African world "as a metaphysical battlefield devoid of all recognizable humanity, into which the wandering European enters at his peril" (Achebe, 1978, p. 9). The white man has no tolerance for traditional Igbo practices or beliefs in their own land. This makes more ardent converts get complete freedom to act on their extreme behavior. One of them is Enoch, who commits a great crime: he unmasks an egwugwu (masked spirit) in public, which is similar to killing a god. His deed leads to the clansmen's burning the church where Enoch is hiding. This event causes direct confrontation between the church and the villagers.

\subsection{Description of the Setting of Place}

The setting of the novel is in the Umuofia and Mbanta villages of the Igbo tribe in Nigeria, Africa around the turn of the $19^{\text {th }}$ century. In order for the readers to get a clear picture of the nature of the setting of place, the author makes use of simile, metaphor, personification, onomatopoeia, and parallelism.

(20) The earth burned like hot coals and roasted all the yams that had been sown. (p. 9)

(21) For two or three moons the sun had been gathering strength till it seemed to breathe a breath of fire on the earth. (p.53)

(22) All the grass had long been scorched brown, and the sands felt like live coals to the feet. (p.53)

(23) Evergreen trees wore a dusty coat of brown. (p.53)

(24) The birds were silenced in the forests, and the world lay panting under the live, vibrating heat. (p.53)

From the simile used in data (20) combined with personification, the readers can feel how hot the weather is. Hot coals are used as a comparison, and it is personified as a thing which can roast the yams. In data (21) personification is also used to describe the sun, which for two or three months has consistently spread its heat on the earth. In data (22), the sand is compared to burning coals and thus it is also very hot to the feet. Because of the brown dust, the evergreen trees are personified as wearing a dusty coat of brown (data 23). Hyperbole is also used to exaggerate the impact of the hot weather. Instead of saying all the creatures in Umuofia, the author uses 'the world' that lies panting because of the great heat (data 24). The figures of speech strengthen the effect of the very hot 
weather to the environment during dry season.

(25) And then came the clap of thunder. (p.53)

(26) It was an angry, metallic and thirsty clap, unlike the deep and liquid rumbling of the rainy season. (p.53)

In data (25) onomatopoeia is used to create an auditory effect similar to the sound they represent. The word clap creates a sound effect that mimics the sudden and loud sound of the thunder that comes. To strengthen the effect, the author also uses parallelism (data 26); the sentence has parallel structure in the use of adjectives. The clap is not just an ordinary clap but an angry, metallic, and thirsty clap, compared to the deep and liquid sounds in the rainy season. The clap is obviously very loud as it is angry; it sounds unpleasantly; and it has a strong desire for water after two or three months of dry season.

(27) A mighty wind arose and filled the air with dust. (p.53)

(28) Palm trees swayed as the wind combed their leaves into flying crests like strange and fantastic coiffure. (p.53)

In data (27), the wind is personified as a thing that can fill the air with dust. It is also personified as a thing that can comb like human being (data 28). Palm trees with their leaves blown by the wind are also personified as a thing that can move slowly from side to side and the flying leaves are compared, in the use of simile, with strange and fantastic hairstyle. The readers can visualize the movement of the palm trees more clearly.

From the explanation above, it is obvious that the use of figures of speech gives a great effect in providing clarity of the things explained to the readers. The nature is important as it has a close connection with the setting of place.

\subsection{Description of the Igbo traditions}

As the Igbo traditions are unique and unfamiliar to the reader, the author makes use of figures of speech to provide emphasis or clarity about them. They are simile, repetition, personification, anaphora, and synecdoche. One of the Igbo traditions is the unique function of drums, which represents the physical connection of the community in Umuofia.
(29) The drums were still beating, persistent and unchanging. Their sound was no longer a separate thing from the living village. It was like pulsation of its heart. It throbbed in the air, in the sunshine, and even in the trees, and filled the village with excitement. (p.18)

(30) Dusk was already approaching when their contest began. The drums went mad and the crowds also. (p.20)

Simile is used in data (29); the sound of the drums is compared to a heartbeat that beats in simultaneously, uniting all the village members. Repetition is also used to emphasize that the sound of the drums is everywhere, all over the village and gives excitement to the village. The drums are also given human attribute in data (30). They are personified as a thing that can go mad. Thus, the figures of speech used are effective in giving a clear picture to the readers and involving the readers' emotion in the actions of the inanimate objects.

Beside drums, other instruments such as ogene (an iron gong), ekwe (hollowed-out wooden instrument), flute, and cannon have their own role in the Igbo tradition.

(31) . . . he heard the ogene of the town crier piercing the still night air. Gome, gome, gome, gome, boomed the hollow metal. Then the crier gave his message, and at the end of it beat his instrument again. (p.3)

(32) An iron gong sounded, setting up a wave of expectation in the crowd. Everyone looked in the direction of the egwugwu house. Gome, gome, gome, gome, went the gong, and a powerful flute blew a high-pitched blast. Then came the voices of the egwugwu, guttural and awesome. The wave struck the women and children and there was a backward stampede. (p.36)

In data (31) the ogene is personified so that it can pierce the still night air. The repetition of the word "gome" is a diacope, which gives auditory effect to the readers as the sound of the hollow metal. The ogene with its sound is used to attract attention of the people to the message the crier wants to announce. In data (32), again the sound of 
the gong, combined with the flute which is personified to be able to blow a high-pitched loud noise, is used to attract the people to something important that is going to happen. In this case, it is the sign of the coming of the egwugwu (the masked spirit of the clan).

(33) The drum sounded again and the flute blew. The house was now a pandemonium of quavering voices: Am oyim de de de de! filled the air as the spirits of the ancestors, just emerged from the earth, greeted themselves in their esoteric language. (p.37)

(34) Am oyim de de de de! flew around the dark, closed hut like tongues of fire. The ancestral spirits of the clan were abroad. (p.37)

A metaphor is used in data (33). The house is in a chaos, "a situation in which there is a lot of noise, activity, and confusion, especially because people are feeling frightenend" ("Pandemonium") as the greetings of the spirits of the ancestors fill the air. In data (34) the greetings in esoteric language used by them are given human quality to fly around the dark closed hut and are compared to tongues of fire. The repetition of the spirits' greetings makes the readers feel the auditory effect whereas the simile gives a clear picture of their movement in the dark hut.

(35) Go-di-di-go-go-di-go. Di-go-go-di-go. It was the ekwe talking to the clan. One of the things every man learned was the language of the hollowed-out wooden instrument. Dum!

Dum! Dum! boomed the cannon at intervals. . . . Somebody was dead. The cannon seemed to rend the sky. Di-go-go-di-go-di-di-go-go floated in the message-laden night air. (Achebe, 1995, p.50)

(36) ... the ekwe carried the news to all the nine villages and even beyond. It began by naming the clan: Umuofia obodo dike! "the land of the brave." Umuofia obodo dike! Umuofia obodo dike! It said this over and over again, and as it dwelt on it, anxiety mounted in every heart that heaved on a bamboo bed that night. (p.50)
In data (35) diacope is also used; the repetition of the sound of the ekwe, the wooden instrument, and the sound of the cannon create rhythm that affects the reader's auditory senses. The ekwe is also personified so that it can talk to the clan through its rhythmic sounds, giving information of what is happening. Together with the repetition of the sound of the cannon, the ekwe is used to spread a message that somebody is dead. The cannon is also personified as it can tear the sky apart with its powerful sound. The ekwe can also carry the news like human being to all the villages (data 36), mentioning the name of the clan over and over again. At this point, repetition of the words "Umuofia obodo dike!" and "over" is to emphasize the frequency and expected effect. It is followed by a personification: anxiety is given quality of a human being to be able to fix its position in every heart. Another personification is also used; the heart is personified as a thing that can heave on a bed. Synecdoche is also used when the heart, as a part of a person, actually represents the whole person, not just the heart.

The sounds of all the instruments precede a warrior's funeral led by an ancestral spirit.

(37) "Ezeudu!" he called in his guttural voice. "If you had been poor in your last life I would have asked you to be rich when you came again. But you were rich. If you had been a coward, I would have asked you to bring courage. But you were a fearless warrior. If you had died young, I would have asked you to set life. But you lived long....” (p.51)

The anaphora, the repetition of the beginning of each clause, is used to give emphasis on the fact that Ezeudu, when he was alive, was a rich and courageous man who lived a long life. From this event, the readers can also understand the unique tradition of the Igbo people better.

\section{CONCLUSION}

From the discussion, it is obviously shown how the linguistic features used by the author in the novel perform their artistic function to help delivering the author's message. The figures of speech play a great role in helping 
to transmit the message the author wants to convey. The figures of speech give a more accurate picture to the readers what kind of a man Okonkwo is; why he resists the new order brought by the white men; and how he decides to commit suicide. In other words, the readers can grasp what the author wants to convey by creating such a protagonist. They are also involved emotionally and thus sympathize with him.

The figures of speech used also give a clear description about the white men, the missionaries who bring Christianity and new government to Umuofia. They come, settle down, and bring changes to the Igbo's social and political life, which break up the Igbo clansmen by their way of converting some of the native to Christianity. By using figures of speech, the author describes clearly the condition of the place the Igbo people live. Situated in Africa, Umuofia is described as having a very hot weather in dry season, which influences everything that lives there. The readers can grasp the author's description about the setting of place which is not familiar to the readers.

Last but not least, the figures of speech are also used to describe the Igbo traditions in details. The author wants to give a clear picture of the unique Igbo traditions which are unfamiliar to the readers. Due to the figures of speech used, the readers can comprehend their traditions clearly.

Chinua Achebe has skillfully made use of a set of figures of speech, such as simile, metaphor, personification, hyperbole, and anaphora in accordance with his purpose. He wants to expose the life of the native Africans so as to be understood better, especially by the whites.

\section{REFERENCES}

[1] Achebe, Chinua. (1978). “An Image of Africa." Research in African Literature, 9(1), Special Issue on Literary Criticism. Indiana University Press, 1-15.

[2] Achebe, Chinua. (1995). Things Fall Apart. Retrieved from https://www.jamiiforums.com/ achebe- chinua

[3] Bogdan, R .C., \& Biklen, S. K. (1997). Qualitative research for education: An introduction to theory and methods. ( $5^{\text {th }}$ ed.). Boston, MA, US: Allyn \& Bacon

[4] Cacciari, C., \& Glucksberg, S. (1994). Understanding figurative language. In M.A. Gernsbacher (Ed.), Handbook of Psycholinguistics (pp. 447-477). San Diego, CA, US: Academic Press.

[5] Chinua Achebe Biography. (2017). Retrieved from https://www.thefamouspeople.com/profiles/ chinua-achebe-1044.php

[6] "Figure of Speech." (n.d.) Retrieved from https://www.merriam-webster.com/dictionary/ figure of speech

[7] Gikandi, S. (1996). "Chinua Achebe and the Invention of African Literature.” Things Fall Apart. Johannesburg: Heinemann

[8] “Harbinger." (2015). Oxford Advanced Learner's Dictionary. $\left(9^{\text {th }}\right.$ ed.). Oxford, UK: Oxford University Press.

[9] Jweid, A.N.A. (2016). The Fall of National Identity in Chinua Achebe's Things Fall Apart. Pertanika Journal Social Sciences and Humanities, 24(1), 529-540.

[10] Leech, G., \& Short, M. (2007). Style in fiction: A linguistic introduction to English fictional prose. ( $2^{\text {nd }}$ ed.). Harlow, UK: Pearson Education.

[11] Lodge, D. (1984). Language of Fiction - Essays in criticism and verbal analysis of the English novel. London, UK: Routledge and Kegan Paul.

[12] Maleki, N., \& Navidi, M. (2011). Foregrounding Achebe's Things Fall Apart: A Postcolonial Study. Canada Social Science, 7(6), 10-15. doi: 103968/j.css. 1923669720110706.078

[13] "Pandemonium." (2015). Oxford Advanced Learner's Dictionary. ( $9^{\text {th }}$ ed.). Oxford, UK: Oxford University Press.

[14] Salami, A., \& Tabari, B.H. (2018). Things Fall Apart and Chinua Achebe's Postcolonial Discourse. International Journal on Studies in English Language and Literature, 6(3), 19-28. doi:10.20431/2347-3134.0603004

[15] Sandelowski, M. (2000). Focus on research methods: Whatever happened to qualitative description? Research in Nursing and Health, 23, 334-340.

[16] Verdonk, P. (2002). Stylistics. Oxford, UK: Oxford University Press.

[17] Wales, K. (2011). A dictionary of stylistics. ( $3^{\text {rd }}$ ed.). New York, NY: Routledge.

[18] Wheeler, K. (2018). Schemes and Tropes. Retrieved from https://web.cn.edu/kwheeler/Documents/schemes_n_tropes.pdf

[19] Widdowson, H.G. (1975). Stylistics and the teaching of literature. London, UK: Longman. 